\title{
Anatomical Study of Bat's Phalanx Bone
}

\author{
Fani Nurrizki*, Hanifah Ika Ristiani, Novita Ambarwati, M. Ja'far Luthfi \\ Biology Education Department, Faculty of Science and Technology, UIN Sunan Kaijaga Jl. Marsda Adi Sucipto No. 1 Yogyakarta 55281, \\ Indonesia. Tel. +62-274-540971, Fax. +62274-519739. \\ Email*: faninurrizki23@gmail.com
}

\begin{abstract}
Bats (Pteropus sp) are nocturnal animals. Bats are mammal that are able to fly, actively foraging at night. During the day time bats spend time for sleeping. It aims to keep the wings membran from sunlight. The habitat of this bat is on large trees. The foot of the bat is adapted to hang upside down, that causing an action against phalanx that calls pressure. Each of phalanx receives a different pressure so that it affect the anatomical structure. This condition present a biomechanical. This study aims to know the effect of pressure on the phalanx. Observation are made by cleaning the phalanx skin and cutting the bones and then seen under the microscope with a magnification of $5 \mathrm{x}$, measurement are taken. The result show that the pressure affect the phalanx anatomical structure that is different thicknesses in each phalanx.
\end{abstract}

Keywords: Bats, phalanx anatomy, pressure

\section{INTRODUCTION}

Bats are mamals that are able to fly. Bats are classified into two sub-orders, namely Megachiroptera and Microchiroptera. There are 72 types of bats that are classified as Megachiroptera and 133 types that are classified as Microchiroptera. Pteropus sp is the largest member of the genus of Pteropodidae which is included in Megachiroptera (Suyanto, 2001). Pteropus is widely distributed in South Myanmar, Thailand, Indochina, Peninsular Malaysia, the Philippines, Java, Sumatra, Kalimantan, the Nusa Tenggara Islands, and scattered islands (Kitchenner, 1990). Bats live in several types of habitats such as caves, natural forests, artificial forests, and plantations. Bats have an alternative in choosing where to roosting. All types of flying fox bats choose a place for roosting to sleep in large trees, while species of insectivorous bats choose place in tree holes, bamboo gaps and caves (Cobert and Hill, 1992).

Bats actively foraging at night or we can call nocturnal. There are two reasons bats are more active at night. The first reason, in the daytime is related to radiation that harms the wing. Bat wings consist of thin skin membranes and are vulnerable to sunlight. Second, bats enhance special adaptations to the senses that support nighttime activities, increasing compatibility with diurnal animals such as birds (Apriandi, 2004). During the day time bats spend time for sleeping, roosting in the tree by their foot.

Bat have small, thin, and slim foot. That small size makes it easy for bats to fly. The difference between bat legs and other mammals is that they are not set up for walking but for hanging upside down. The hip joint is not lifted by the bat standing (Neuweiler, 2000). The foot of a bat consists of 5 phalanges equipped with claws, the claws provided can support the bat, support the feathers and ears, and help move the perch (Whitaker and William, 1998). Bats hang by using phalanges so cause an action in the form of pressure on each phalanx of bats. This causes a difference in thickness in the phalanx of bats due to pressure. This study aims to know the effect of pressure on the phalanx.

\section{MATERIAL AND METHODS}

This study uses bats (Pteropus sp). The bat's phalanx has been cut with scalpel from the foot, and skinned. Observation of phalanx anatomical structure had been done by cutting phalanx with cleaver knife transversely in parts $\mathrm{A}$ and $\mathrm{B}$.

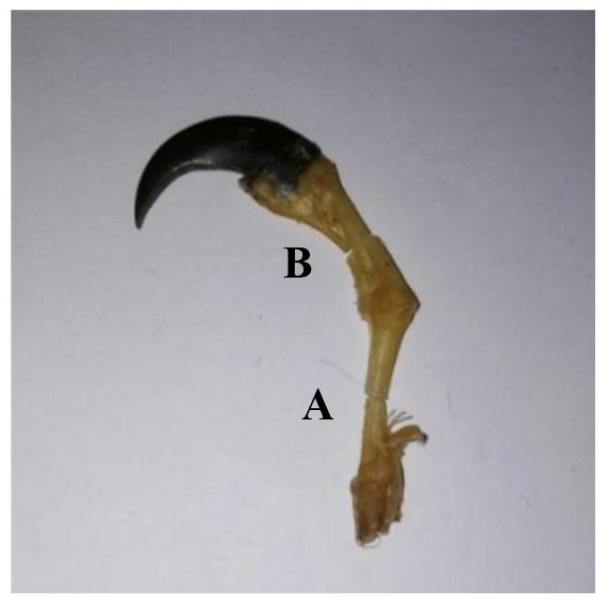

Figure 1. Phalanx cutting area

After that, measure the thickness of the bone with the calipers in the B section that has been cut off. The data 
obtained in the form of numbers on a mm scale. Then the part is observed using a microscope. The result of these observation are documented.

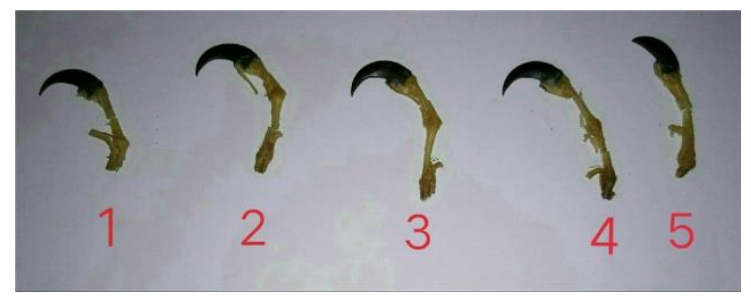

Figure 2 Bat's Phalanx

\section{RESULT AND DISCUSSION}

Base on observation, the result obtain the different bone thickness on phalangus $1,2,3,4$, and 5 .

Table 1. Result of Phalanx Bone Thickness Measurements Phalanx.

\begin{tabular}{lllll}
\hline & $\begin{array}{l}\text { Upside } \\
(\mathbf{m m})\end{array}$ & $\begin{array}{l}\text { Bottom side } \\
(\mathbf{m m})\end{array}$ & $\begin{array}{l}\text { Left side } \\
(\mathbf{m m})\end{array}$ & $\begin{array}{l}\text { Right side } \\
(\mathbf{m m})\end{array}$ \\
\hline Phalanx 1 & 0,45 & 0,55 & 0,35 & 0,30 \\
Phalanx 2 & 0,50 & 0,50 & 0,40 & 0,45 \\
Phalanx 3 & 0,55 & 0,60 & 0,40 & 0,45 \\
Phalanx 4 & 0,45 & 0,70 & 0,40 & 0,45 \\
Phalanx 5 & 0,55 & 0,50 & 0,55 & 0,45 \\
\hline
\end{tabular}

Based on the table 1, it can be seen that all phalanxs have a bone thickness of the upper-lower side greater than the left and right side.

The picture (Figure 3) shows that there is a different thickness on the phalanx. The topbottom is thicker than the side (right-left). Phalanges 1 appear oval shaped. Then on phalanges 2, has a rounded shape. At phalang 3 oval shaped but thicker. In phalanges 4 , the shape is slightly oval while in phalanges 5 , it has a rounded but irregular shape. There are different thicknesses on each side due to different pressures (direction). Reece (2009) said that the different thickness of bone can occurs in respone to stress placed on bone. The organization of bone changes to meet mechanical and other stresses placed on the bone, and it respresents a balance between bone formation and bone resorption. The wall will be thicker on the axis leading to and away from the load. In this case on the top-bottom is the main axis of pressure so that the section has a thicker bone wall compared to the other side. Nickel (1977) said that the bone may then compromise between the beam and tube by becoming oval in cross section, with the long axis of the oval in the direction of the dominant load and with thicker walls on the sides toward and away from the load. Phalanges 2, phalanges 3 , and phalanges 4 are part of phalanges that have the usual force, causing the three phalanges to have a thickness of bone wall greater than phalanx 1, and phalanx 5 mainly on the top-down sides.

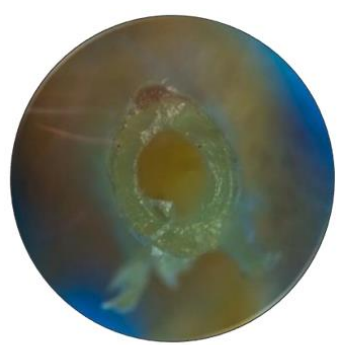

(A)

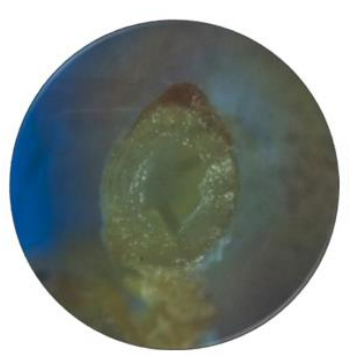

(C)

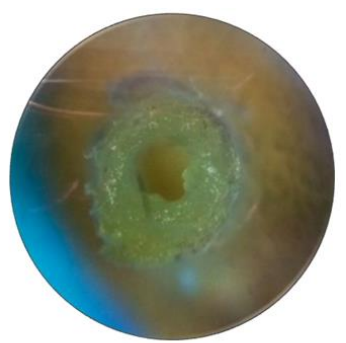

(B)

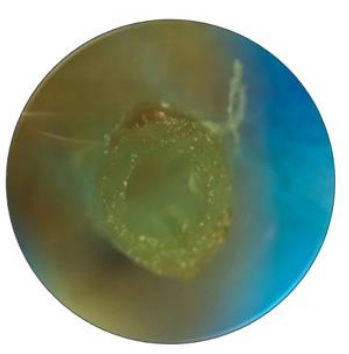

(D)

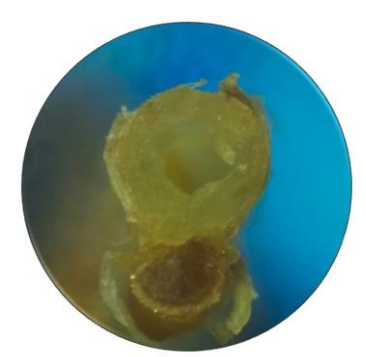

(E)

Figure 3. (A) Phalanx 1; (B) Phalanx 2; (C) Phalanx 3; (D) Phalanx 4; (E) Phalanx 5

\section{CONCLUSION}

The thickness of the bone wall in the phalanx is determined by the presence of a different usual force. Phalanges 2, phalanges 3 , and phalanges 4 are the main phalanges for roosting that have a thicker bone wall thickness than phalanges 1 , and phalanges 5 mainly on the top-down sides.

\section{REFERENCE}

Apriandi, J. 2004. "Keanekaragaman dan Kekerabatan Jenis Kelelawar

Berdasarkan Kondisi Fisik Mikroklimat Tempat Bertengger pada Beberapa Buah di Kawasan Buah Budawang”, dalam skripsi, Institut Pertanian Bogor, Bogor.

Cobert, G. B and J. E. Hill. 1992. The Mammals of the Indomalaya Region: A Systematic Review. New York: Oxford University Press. 
Kitchener, T dkk. 1990. Wild Mammals of Lombok Island Nusa Tenggara, Indonesia: Systematic and Natural History. Australia: Western Australian Museum.

Neuweiler, Gerhard. 2002. The Biology of Bats. New York: Oxford University Press.

Nickel, R., August S., and E. Seiferle. 1977. Anatomy of The Domestic Birds. New York: Parey
Reece, William O. 2009. Functional Anatomy and Physiology of Domestic Animals 4th ed. USA: A John Wiley \& Sons, Inc., Pulication

Suyanto, A. 2001. Kelelawar di Indonesia. Bogor: Pusat Penelitian dan Pengembangan Biologi-LIPI.

Whitaker, John O. and William J. Hamilton. 1998. Mammals of The Eastern United States Third Edition. London: Cornel University Press. 
THIS PAGE INTENTIONALLY LEFT BLANK 